\title{
Environmental Protection in Industry 4.0. Opportunities and Threats in Selected Areas
}

\author{
Bożena Gajdzik, Beata Oleksiak \\ Silesian University of Technology, Poland \\ Pavlína Pustějovská, Markéta Tkadlečková \\ VSB-TUO, Technical University of Ostrava, Czech Republic
}

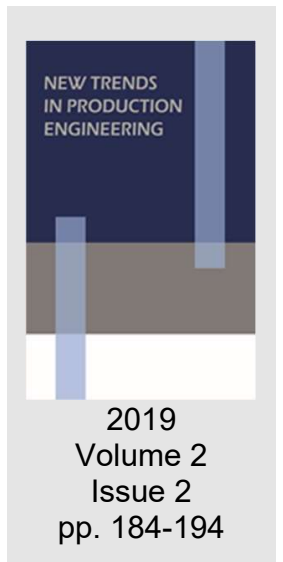

Date of submission to the Editor: 09/2019

Date of acceptance by the Editor: 11/2019

\section{INTRODUCTION}

The fourth industrial revolution is based on the growing share of new technologies in the economy, in particular in the production sector. Industry 4.0 though initially introduced in 2011 in Germany, the official announcement as a strategic German initiative to revolutionize the manufacturing industry through the use of technology was officially unveiled in 2013 (Xu et al. 2018). Industry 4.0 is a current trend in manufacturing industry. Industry 4.0 should be understood as a collective term for new technologies: IoT, loS, Cloud Computing, Big Data, Analitics Data, Rapid Prototyping, Augmented Reality and concept of network system of value chain with Blockchain Technology (Hermann \& Pentek, 2015; Hermann, et al., 2016, Schwab, 2016; Yen et al., 2014). The feature of Industry 4.0 is the integration of physical world in the organization and the cyber world through technologies of the fourth industrial revolution (Bassi, 2017; Fonseca, $2018 \mathrm{Xu}, \mathrm{Xu}$, \& Li, 2018). Industry 4.0 enforces modification of traditional perception of production, in which the processes of transformation of elements at the entry into the production system into elements at the exit final products were carried out in long cycles and with a significant involvement of human labor $(29.82 \%$ of the population professionally employed in industry in 2018 in Poland) (Statistics Poland, 2018, Table 5 - Employment). The production is a part of CPS. The CPS (Cyber Physical System) concept was defined by J. Truchard, who introduced the system as a combination of the virtual and physical world (Lee, 2008). In fact, CPS is the integration of a computer system, a communication system and a control system (Shi et al., 2011). Data from millions of sensors connected by the Internet of Things provides real-time information necessary to optimize production, and robotization in production allows to increase its efficiency (Almado Lobo, 2015; Georgakopoulos et al., 2016). The key roles of CPS are to achieve the agile and dynamic requirements of production. In addition, it should also aim to improve the efficiency and effectiveness of the complete organization (Lu, 2017; Zanero, 2017, Qin et al., 2016). The ongoing transformation of production in Industry 4.0 
is inseparable from digital information technologies. According to the report: Accelerating Clean Energy through Industry 4.0, published by UNIDO in 2017, this approach is a challenge, but also a chance for the environment protection. Digital technologies offer many benefits, including increasing the use of renewable energy in production, reducing carbon dioxide emissions, increasing energy efficiency in industry or increasing the productivity of enterprises (UNIDO, 2017). Industry 4.0 is still continuing the concept of sustainable development. The need to integrate the dimensions of development: social, economic and environmental, is defined as sustainability - sustainable development or business sustainability (Agenda 21). The existing business models will continue to take into account its impact on the environment. In this new reality consumption and production are responsible (12-th target from SDGs - Sustainable Development Goals, out of 17 to be implemented by 2030). Document: Transforming Our World: The 2030 Agenda for Global Action adopted at the UN Summit in New York, 25 September 2015, setting the basic goals of the countries until 2030. From the perspective of environmental protection and the development of Industry 4.0, the most important goals are: building a stable infrastructure and supporting innovation, obtaining clean energy, climate protection and clean water (SDGs) (online: Platform of Sustainable Development). Polish enterprises increasingly put on integrated technologies. Their goal is to reduce the amount of pollutants produced by modifying technological processes. In this way, production becomes "cleaner" and more environmentally friendly. According to the report, the volume of fixed capital expenditure for environmental protection in 2016 amounted to approximately PLN 6.5 billion. Most, more than a third, were allocated to the protection of atmospheric air and climate (information in Chemical Review, 2018). Integrated technologies are the result of the development of the sustainable business model and the consequence of the modification of environmental strategies from the "end of pipe" strategy (industry reaction measures) to the prevention strategies (industry preventive actions) (Gajdzik, 2009; Wieszała \& Gajdzik, 2010). In the new situation of industry the environmental aspects in enterprises will be changed but typical structure of them will be the same (Gajdzik, 2012). Sustainability is the key feature in Industry 4.0. Sustainability is realized in organization (Stock \& Seliger, 2016; Bonilla, et al., 2018; Ford \& Despeisse, 2016) and behind it (Vranken, 2017).

\section{ENERGY MANAGEMENT - INTELLIGENT SYSTEMS IN THE ENERGY SECTOR}

Objective 7 of SDGs is gaining clean energy. In Industry 4.0 smart factories cooperate with energy systems in the context of sustainable energy. Smart factories are part of the energy systems in the economy. The essence of this cooperation is focused on the increase of the share of renewable energy in total energy consumption and improvement of energy efficiency in the network system of entities producing and using energy with a significant diversification 
of energy sources (Figure 1). The smart factories is the key feature of Industry 4.0 (Burke et al., 2017).

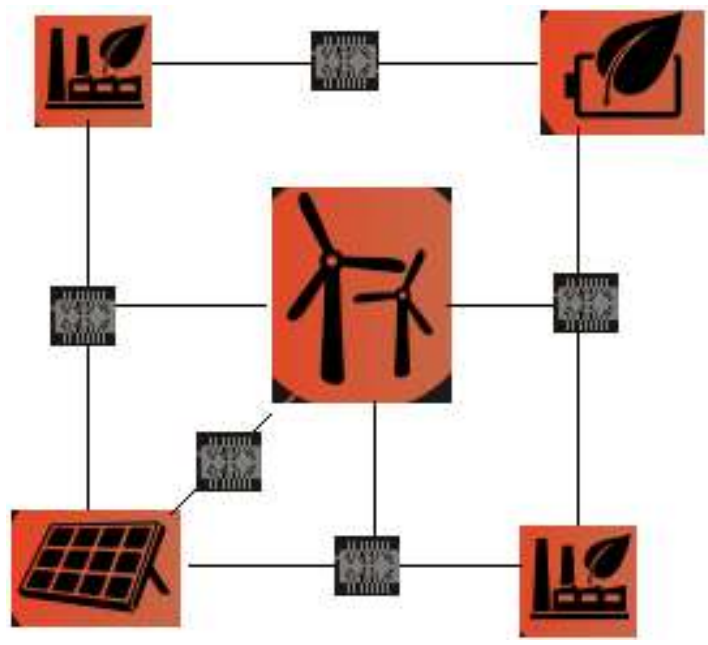

Source: (UNIDO, 2017)

Fig. 1 Network energy supply in Industry 4.0

In the power Industry 4.0, the importance of information systems, integrated into smart grids - smart grid - and power plants (a trend consisting in moving away from point solutions to consolidation of solutions) will increase. The network system is a distributed structure of entities (objects) that use renewable sources to generate electricity, such as the sun or wind. Computer systems monitor the operation of individual devices, e.g. turbines or entire power plants, as well as the entire farm(online: inno-energy-PP_39).The energy system is therefore computerized in systems starting with individual devices up to whole energygenerating structures and objects. Thanks to the far-reaching integration of the system - regardless of whether we are dealing with one turbine or the entire farm - the operator interface looks the same. Computer systems allow for monitoring the equipment status and production level (which increases energy efficiency), as well as predicting future production based on forecasts (e.g. weather, sales) and the technical condition of the installation (Predictive Energy). In the field of prediction of production and energy consumption, among others neural networks (Wang, 2014), which enable the development of models based on many aspects, e.g. wind speed, sun exposure, ambient temperature, temperature and atmospheric pressure, the number of operating energy generating devices. By collecting all of these data (from different segments) in one place it is possible, for example, to plan the maintenance work of installations so that they have a minimal impact on electricity production.

The network structure of the energy market, apart from participants on the supply side - energy generators and distributors, is also created by participants of the energy demand side, i.e. smart houses made of materials preventing energy losses, with devices with low energy consumption and energy consumption monitoring equipped with sensors. and computer systems for managing energy consumption in homes. 
New network systems of production and energy facilities, facilities and equipment equipped with IT and computer systems, access to Big Data and the Internet of Services (Internet of Services - loS) create new energy industry structures known as: intelligent systems in the energy sector. These intelligent systems with real-time data are used not only to increase electricity production, but above all to make flexible purchases of electricity by customers. In grid systems, energy producers use access to databases, which is not required by transmission system operators and energy producers, among others maintaining your own IT infrastructure, necessary for contact with the final energy recipient (online: inno-energy-PP_39). All these facilities have the effect of increasing the rationality of energy management and better production flexibility (Smart Energy) and minimizing the costs of energy production and consumption. Efficiency obtained in intelligent energy systems translates into environmental protection (Figure 2).

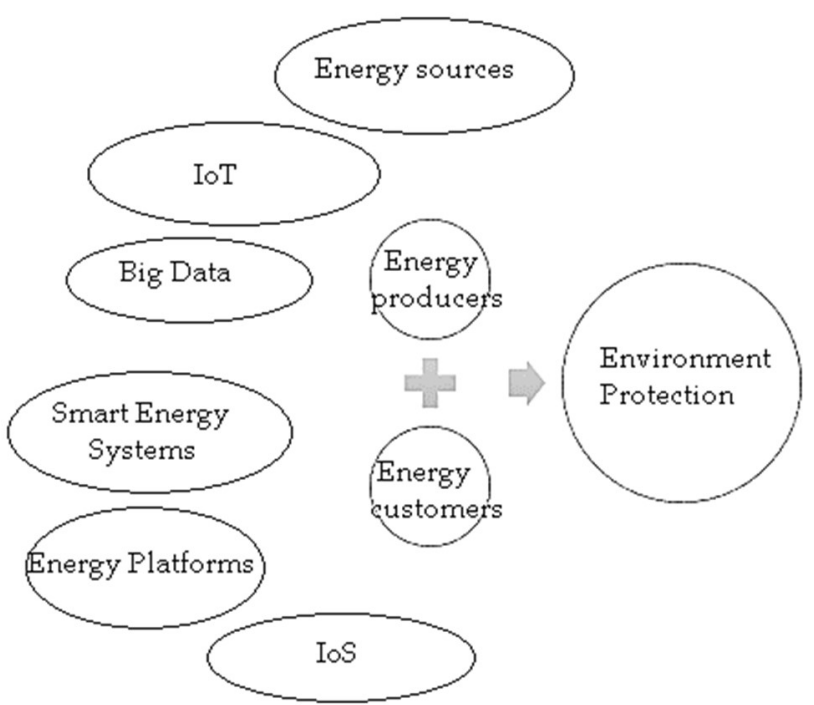

Fig. 2 Energy system in Industry 4.0

It is anticipated that the new technology of Industry 4.0 will increase electricity consumption, especially in those countries that have not yet achieved a $50 \%$ level of energy diversification, Poland also belongs to these countries. According to "Forecasts of demand for fuels and energy until 2030". published by the Ministry of Economy (document from 2009), electricity consumption in Poland will increase by $55 \%$, gas by $29 \%$, and petroleum products by $27 \%$ (Modrzejewski, 2019).The condition for improving the situation in the energy sector are strategies for improving energy efficiency (energy efficiency, the more important it is that the industrial sector accounts for one third of global final energy consumption and $40 \%$ percent of global $\mathrm{CO}_{2}$ emissions). "According to the report of the International Energy Agency, the global value of investments in the development of energy efficiency only in 2016 exceeded 230 billion dollars. At the same time, by 2030 the European Union plans to reduce energy consumption by $30 \%$. Activities aimed at increasing energy efficiency affect many aspects related to, among others with maintaining energy security, 
reducing energy costs and protecting the natural environment" (Elmodis, 2018). In Poland in October 2016, the Energy Efficiency Act came into force, defining the formal rules and obligations of entrepreneurs, aimed at improving energy efficiency, including by implementing innovative solutions, preparing an energy audit of the company and improving overall efficiency in various sectors of the economy. In Poland, in the years 2006-2016, there was an improvement in energy efficiency. Primary energy consumption decreased in this period by more than $3 \%$ annually, and final energy consumption by over $2 \%$. The fastest pace of energy efficiency improvement was recorded in the industry (Figure 3), the average annual efficiency improvement rate in $2006-2017$ was $0.8 \%$ (Statistics Poland, 2018/Efficiency of energy using).

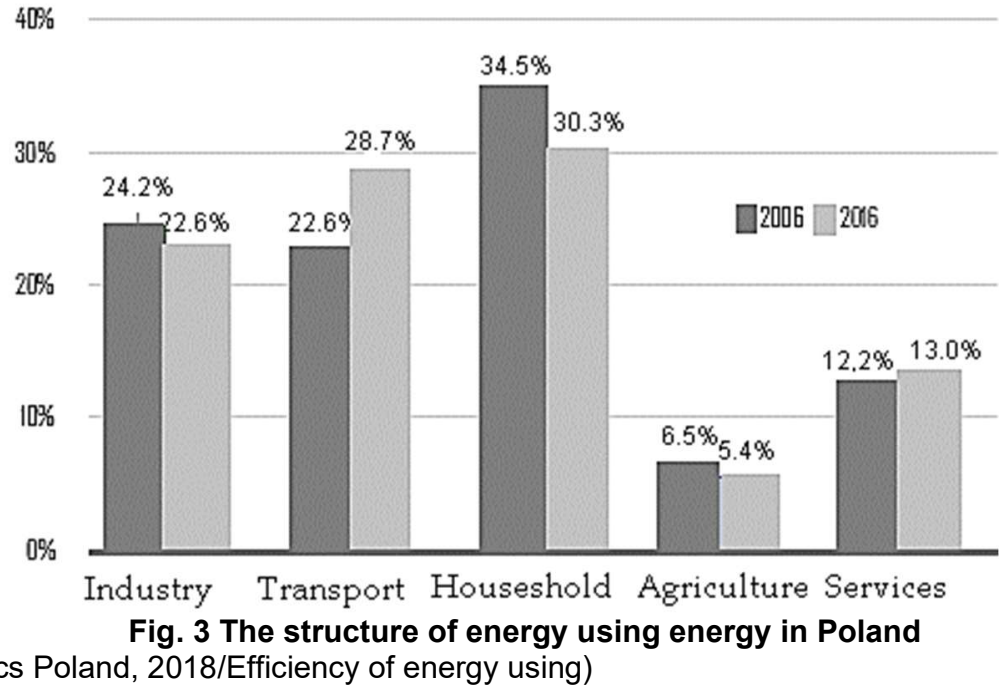

Source: (Statistics Poland, 2018/Efficiency of energy using)

\section{MATERIALS MANAGEMENT - CIRCULAR ECONOMY AND RECYCLING}

In addition to energy, also the economy of other resources (raw materials) in Industry 4.0 will be intensified in terms of rationality of their use. The UN member states are intensifying their efforts to modernize infrastructure and modernize industry in such a way as to ensure its sustainable development, and the key aspect of the implementation of these assumptions is care for the environment and its resources. Transforming Our World: The 2030 Document Agenda for Global Action requires countries to more effectively use resources and use clean, environmentally friendly technologies and production processes.

The new CPPS architecture used in Industry 4.0 helps producers to manage raw materials needed for production rationally. In Industry 4.0, CSR capabilities in the scope of information transfer and tracking of production and per production processes are increased, including traceability of resources (materials) - CSR along with loT tracks the flow of materials and energy. In addition, it facilitates the handling of increasingly complex industrial processes, helps in the optimization of resources and enables faster response to changes in the business environment. Platform compatibility will allow you to order materials and in optimal quantity (if possible from different sources) (online: Schneider Electric, 2017). In addition, intelligent and learning machines 
(learning from mistakes, copying the model algorithms of actions) are able to better manage the material used for production than man (greater accuracy, precision, eg material processing, material cutting.

In the new production systems, the emphasis is put on the production of personally manufactured products, which means that the machines will use exactly as much material as the physical characteristics of the customer ordering. Lean production in Industry 4.0 means, among others eliminating production for stock (production to warehouse). The concept of Lean Management is still actual in Industry 4.0 (Sony, 2018). Deliveries of personalized products are practically done "on the spot" (Gajdzik, 2019). Industry 4.0 also includes new materials such as graphene, self-cleaning clothes, and ceramics that emphasize energy (Bujak, 2017). These new materials also affect the optimization of product management and use. Intelligent products (product memory) provide information about what happens to them throughout the life cycle through the information provided by the producers (Olszewski, 2016). The closed circuit economy is particularly important in new technology (circular economy) (George et al., 2015; Ghisellini et al.,2016; Lieder and Rashid, 2016) and fast capturing of materials for re-use (upcykling) (Schwab, 2016). The Ellen MacArthur Foundation has developed a set of six activities in the scheme ReSOLVE, which can help entrepreneurs and governments to switch to a circular economy. These are: regeneration (Regenerate), sharing (Share), optimization (Optimize), closing circuits (Loop), virtualization (Virtualise) and exchange (Exchange) (Paca, Deloitte, 2018). Recycling of various secondary raw materials is carried out. When quoting GUS data in 2016, the recovery and recycling levels for: end-of-life vehicles calculated for the European Union amounted to: $92.7 \%$ for recovery and $87.1 \%$ for recycling (Poland ranked fifth); the weight of collected waste electrical and electronic equipment from $1.6 \mathrm{~kg}$ per capita in Latvia to $19.6 \mathrm{~kg}$ per capita in Norway and $16.5 \mathrm{~kg}$ per capita in Sweden (differences in waste of electrical and electronic equipment result from differences in consumption levels and consumption, as well as the efficiency of existing waste collection systems in individual countries,), recovery of packaging waste: Germany, Italy, France at a level above 7500 thousand tonnes (Poland in the sixth place), collected batteries and accumulators: Germany, Great Britain, France over 13,000 tonness (Poland ranked fifth) (Statistics Poland, 2018/Environment Protection).

Solutions offered by the Industrial Internet of Things (unification of software, standards) in addition to the savings associated with the earlier detection of anomalies, avoiding downtimes or reducing the amount of consumed materials and energy, reduces the amount of carbon dioxide released into the environment (Janikowski, 2016). It is assumed that new technological solutions with loT instrumentation can reduce the negative impact on the environment, even by several dozen percent annually (BCG, 2012). Access to information flowing from smart factories can increase the control of government institutions over the functioning of the business and its impact on the environment. 


\section{COSTS OF ENVIRONMENTAL PROTECTION AND EXPENDITURES}

An unquestionable barrier to the development of new technologies in the field of environmental protection are the growing costs of environmental protection of the industry and household expenses in connection with environmental protection (consumer participation). When quoting Statistics Poland data, the gross running costs incurred for environmental protection since 2005 are systematically growing. In 2017, they amounted to PLN 39 billion (Figure 4).

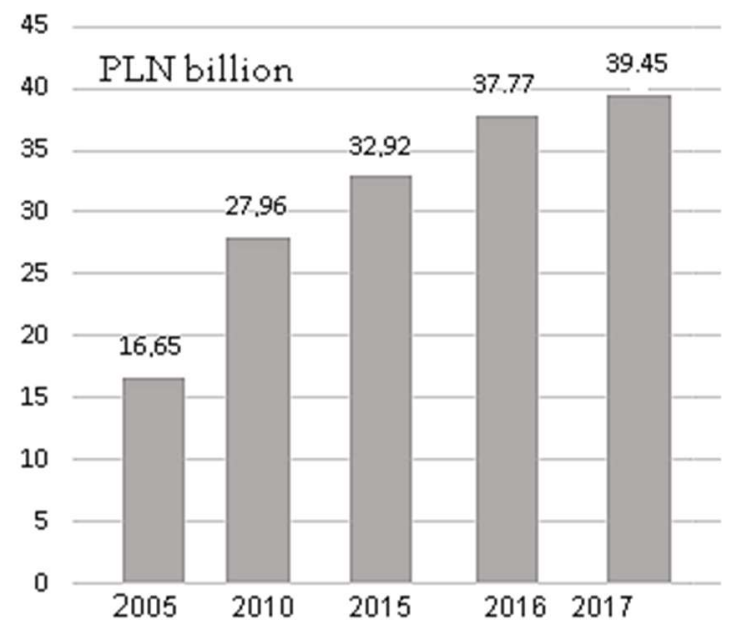

Fig. 4 Costs of environmental protection in Poland in 2005-2017 Source: (Statistics Poland, 2018/Environmental protection)

Current costs of environmental protection (gross) are costs of service and maintenance of activities (technology, process, equipment) related to environmental protection. Their main purpose is to prevent, reduce, neutralize or eliminate pollution and any other environmental losses resulting from the current operations of the unit. They include costs of own activities, including costs related to the operation and maintenance of environmental protection devices ("pipe end" and preventing pollution) and costs of activities provided by external entities, service fees (for wastewater treatment and waste disposal), ecological fees and control costs, monitoring, laboratory tests (Statistics Poland, 2018/Environmental protection).

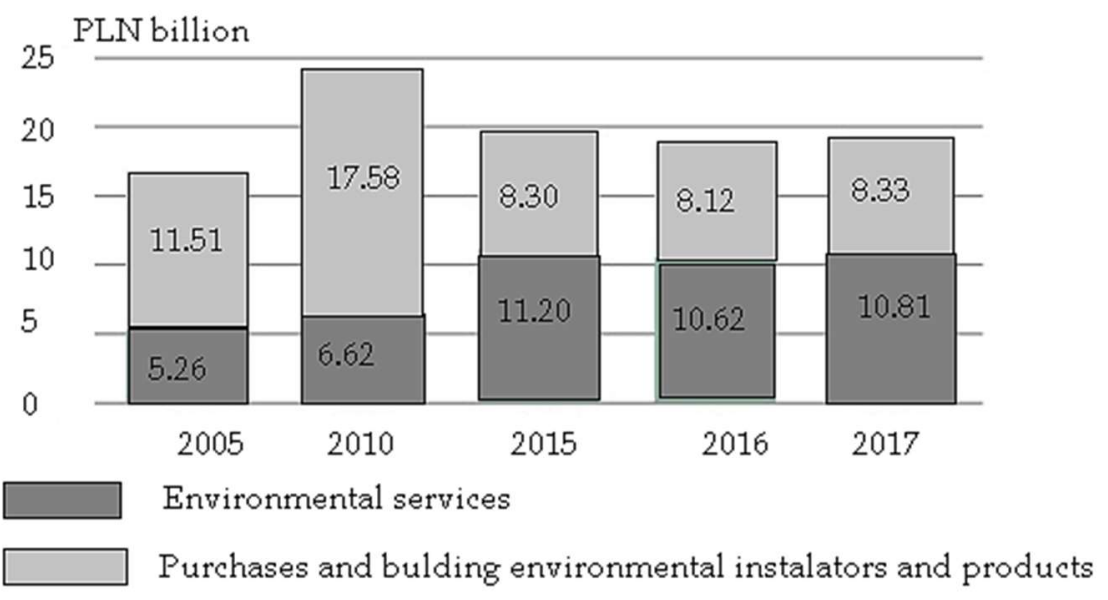

Fig. 5 Expenditures for environmental protection in Poland in 2005-2017 Source: (Statistics Poland, 2018/Environmental protection) 
Expenditure on environmental protection of households is also growing. According to Statistics Poland data, in 2017 they amounted to PLN 19.2 billion, of which expenditure on services related to environmental protection accounted for $57 \%$, while expenditure on the purchase, assembly and construction of equipment and related products was the remaining $43 \%$ (Figure 5). Among expenses for services related to environmental protection, fees for waste water collection, discharge to sewage systems or sewage treatment predominate. They account for over $60 \%$ of expenditure on services. Other expenses are fees for waste disposal.

\section{CONCLUSION}

Concluding the presented directions of changes, the discussed ranges were sorted into categories: opportunities and barriers to environmental protection. 4.0 In the area of: energy, opportunities are: strongly diversified network structures of energy producers and suppliers with traditional and renewable energy sources, flexible cooperation between energy producers and consumers, access to real-time data (IoT, Big Data), which contributes to predicting energy consumption and optimizing energy production and consumption. A threat to environmental protection in the area of: energy is a growing demand for energy (Industry 4.0 technology is energy-intensive). On the other hand, in the area of materials, the chance is the materials themselves (innovation of materials), precision of material use by industrial robots (less waste), recycling of raw materials and a fast reprocessing cycle. The biggest barrier to environmental protection are the growing costs of environmental protection and expenditure on environmental protection of consumers/households. Meeting the requirements of Industry 4.0 will in the coming years be associated with new investments in industry, and manufactured products with a completely new use value have a higher price than traditional products.

\section{REFERENCES}

Accelerating Clean Energy through Industry 4.0. [online], UNIDO, 2017, p. 8. Available at: https://www.unido.org/sites/default/files/2017-08/REPORT_ Accelerating_clean_energy_through_Industry_4.0.Final_0.pdf [Accessed:Aug.2017].

Agenda 21. Proceedings of United Nations Conference on Environment \& Development. Brazil, Rio De Janerio, UN, 1992.

Almado Lobo, F. (2015). The Industry 4.0 revolution and the future of Manufacturing Execution Systems (MES). Journal of Innovation Management, (3-4).

Analizy statystyczne. Ochrona środowiska/Environmental protection (in Polish). (2018). [online] GUS Warszawa, pp. 156-160. Available at: ochrona_srodowiska_2018.pdf

Bassi, L. (2017). Industry 4.0: Hope, hype or revolution? In 2017 IEEE 3rd International Forum on Research and Technologies for Society and Industry (RTSI) Italy, pp. 16.

Bonilla , S., Silva Helton R. O., Marcia Terra da Silva, Gonçalves, R, F. and Sacomano J. B. (2018). Industry 4.0 and Sustainability Implications: A Scenario-Based Analysis of the Impacts and Challenges. Sustainability, 10, 3740, pp. 1-24. MDPI. Available at: www.mdpi.com/journal/sustainabili 
Burke, R., Mussomeli, A., Laaper, S., Hartigan, M. and Sniderman, B. (2017). The smart factory: Responsive, adaptive, connected manufacturing. Deloitte Insights, August, 31, pp. 1-19.

Bujak, A. (2017). Rewolucja przemysłowa -4.0 i jej wpływ na logistykę XXI wieku. Autobusy, 6, pp. 1338-1344.

Efektywność wykorzystania energii w latach 2006-2016/Efficiency of energy using (in Polish). [online] Statistics Poland. Warsaw. Available at: https://stat.gov.pl/ obszary -tematyczne/srodowisko-energia/energia/efektywnosc-wykorzystaniaenergii-w-latach-2006-2016,9,1.html. [Accessed 15 June 2018].

Dlaczego strat-upy są tak ważne dla energetyki w świetle Industry 4.0. Polski Przemysł. [online] July 2017. Available at: https://polskiprzemysl.com.pl/wpcontent/uploads/inno-energy-PP_39.pdf

Ford, S., Despeisse, M. (2016). Additive manufacturing and sustainability: An exploratory study of the advantages and challenges. Journal Clean. Production, 137 , pp. 1573-1587.

Fonseca, L. M. (2018). Industry 4.0 and the digital society: Concepts, dimensions and envisioned benefits. In Proceedings of the International Conference on Business Excellence, 12, pp. 386-397.

Gajdzik, B. (2012). Comprehensive classification of environmental aspects in metallurgical enterprise. Metalurgija, 51 (4), pp. 541-544.

Gajdzik, B. (2009). Environmental aspects, strategies and waste logistic system based on the example of metallurgical company. Metalurgija, 48 (1), pp. 63-67.

Gajdzik, B. (2019). Struktura łańcucha dostaw w logistyce 4.0 w przemyśle stalowym. Gospodarka Materiałowa i Logistyka, 71(4). DOI 10.33226/1231-2037.2019.4.2.

George, D.A., Lin, B.C. and Chen, Y. (2015). A circular economy model of economic growth. Environmental Modelling \& Software, 73, pp. 60-63.

Georgakopoulos, D., Jayaraman, P.P., Fazia, M., Villari, M., and Ranjan, R. (2016). Internet of Things and edge cloud computing roadmap for manufacturing. IEEE Cloud Computing, 3(4), pp. 66-73.

Ghisellini, P., Cialani, C., Ulgiati, S. (2016). A review on circular economy: the expected transition to a balanced interplay of environmental and economic systems. Journal of Cleaner Production,114, pp. 11-32.

Hermann, M., Pentek, T. (2015). Design Principles for Industrie 4.0 Scenarios: A Literature Review. Technische Universität Dortmund Fakultät Maschinenbau, Working Paper, No. 01.

Hermann, M., Pentek, T., and Otto, B. (2016). Design principles for Industrie 4.0 scenarios. In: System Sciences (HICSS), 49 ${ }^{\text {th }}$ Hawaii International Conference, pp. 3928-3937.

Industry $4.0 \mathrm{w}$ energetyce. [online] Available at: https://polskiprzemysl.com.pl/wpcontent/uploads/inno-energy-PP_39.pdf

Janikowski, R. (2016). W kierunku ochrony środowiska 4.0. Prace Naukowe Uniwersytetu Ekonomicznego we Wrocławiu, nr 453. Ekonomia środowiska i polityka ekologiczna, pp. 38-50.

Lee, E. A. (2008). Cyber physical systems: Design challenges, in Object Oriented RealTime Distributed Computing (ISORC). $11^{\text {th }}$ IEEE International Symposium on. IEEE, 2008, pp. 363-369.

Lieder, M., Rashid, A. (2016). Towards circular economy implementation: a comprehensive review in context of manufacturing industry. Journal of Cleaner Production, 115, pp. 36-51.

Lu, Y. (2017). Industry 4.0: A survey on technologies, applications and open research issues. Journal of Industrial Information Integration, 6, pp. 1-10.

Modrzejewski, H. (2019). Rynek energetyki w Polsce czeka prawdziwa rewolucja. Dzięki innowacjom ma być taniej i bardziej ekologicznie. Tygodnik Wprost. [online] 20 May 2019 Available at: https://www.wprost.pl/tygodnik/10126077/energia40.html 
Ochrona środowiska - jedno z największych wyzwań Przemysłu 4.0. P.M.K. [online] 2 May 2018. Elektrotechnik Automatyk. Info Branżowe. Elmodis. Availabe at: https://www.elektrotechnikautomatyk.pl/info-branzowe/Ochrona-srodowiskajedno-z-najwiekszych-wyzwan-Przemyslu-4-0,384,1

Olszewki, M. (2016). Mechatronizacja produktu i produkcji - przemysł 4.0. Pomiary, Automatyka, Robotyka, 3, pp. 13-28.

Paca, D. (2018). Jak wprowadzić circular economy w firmie? Sustainability Insights, 1. Available at: https://www2.deloitte.com/pl/pl/pages/zarzadzania-procesami-istrategiczne/articles/sustainability-insights/jak-wprowadzic-circular-economy-wfirmie.html

Platforma Celów Zrównoważonego Rozwoju [online] (in Polish). Available at: http://www.un.org.pl/

Qin, J., Liu, Y., and Grosvenor, R. (2016). A categorical framework of manufacturing for industry 4.0 and beyond. Procedia Cirp, 52, pp. 173-178.

Rocznik statystyczny przemysłu 2017. Statistics Poland. Warsaw. On the based on: Chemical Review. [online] 26 April 2018. Ochrona środowiska - jedno z największych wyzwań Przemysłu 4.0. Available at: https://chemical.pl/wiadomosci/sp/12856ochrona-srodowiska-jedno-z-najwiekszych-wyzwan-przemyslu-4-0

Schwab, K. (2016). The Fourth Industrial Revolution. World Economic Forum. Deloitte.

Shi, J., Wan, J., Yan, H., and Suo, H. (2011). A survey of cyberphysical systems, in Wireless Communications and Signal Processing (WCSP). International Conference on. IEEE, 2011, pp. 1-6.

Schneider Electric [online] 18 May 2017. Available at: https://nowaenergia.com.pl/2017/05/18/czy-wykorzystamy-potencjal-przemyslu-4-0/

Sony, M. (2018). Industry 4.0 and lean management: a proposed integration model and research propositions. Production \& Manufacturing Research. An Open Access Journal, (6). Taylor \& Francis online. Availabe at: https://www.tandfonline.com/doi/full/10.1080/21693277.2018.1540949

Stock, T., Seliger, G. (2016). Opportunities of sustainable manufacturing in Industry 4.0.Procedia Cirp, 40, pp. 536-541.

The Role of ICT in Driving a Sustainable Future, Global e-Sustainability Initiative, The Boston Consulting Group (BCG), Inc, GeSi Smarter2020. [online] December 2012. Available at: http://gesi.org/SMARTer2020

Transforming Our World: The 2030 Agenda for Global Action. [online] In Polish. Available at: https://www.mos.gov.pl/fileadmin/user_upload/mos/srodowisko/ miedzynarodowe_aspekty_zrownowazonego_rozwoju/Polska_wersja_jezykowa_ dokumentu_Przeksztalcamy_nasz_swiat._Agenda_na_rzecz_zrownowazonego_r ozwoju_2030.pdf [Accessed: July 2019].

Wang, D. Wu, H.(2014). Application of BP neural network to power predioction of wind power generation unit in microgrid. Engineering Technology and Applications. London.

Wieszała, R., Gajdzik, B. (2010). The effectiveness of environmental management in a metallurgical company's sustainable development. Metalurgija, 49 (4), pp. 353355.

$\mathrm{Xu}, \mathrm{L}$. D., Xu, E. L. and Li, L. (2018). Industry 4.0: State of the art and future trends. International Journal of Production Research, 56(8), pp. 2941-2962.

Yen, C.-T., Liu, Y.-C., Lin, -C.-C., Kao, -C.-C., Wang, W.-B., \& Hsu, Y. R. (2014). Advanced manufacturing solution to Industry 4.0 trend through sensing network and Cloud Computing technologies. In: Automation Science and Engineering (CASE), IEEE International Conference, pp. 1150-1152.

Vranken, H. (2017). Sustainability of bitcoin and blockchains. Current Opinion in Environmental Sustainability, 28, 1-9.

Zatrudnienie i wynagrodzenie w gospodarce narodowej w 2018 roku (Employmenttable 5). Statistics Poland, Warsaw. Availabe at: https://stat.gov.pl/obszarytematyczne/rynek-pracy/pracujacy-zatrudnieni-wynagrodzenia-koszty- 
pracy/zatrudnienie-i-wynagrodzenia-w-gospodarce-narodowej-w-2018roku, 1,33.html

Zanero, S. (2017). Cyber-physical systems. Computer, 50(4), pp. 14-16.

\begin{abstract}
.
In recent years, the importance of production in cyberphysical systems - CPS characteristic of the new industry concept, which is Industry $4.0-1$ 4.0, is gaining importance. Industry 4.0 enforces modification of traditional perception of production. The basis for changes in Industry 4.0 has become Internet of Things - IoT, which gives the opportunity to connect and communicate with each other such areas as mobile solutions, cloud computing, sensors, analytics and cyber security. By new technology, areas that previously operated in enterprises as separate systems can be combined and create new opportunities for industrial production (modernization of production methods and reduce employment). Industry 4.0 brings with it a number of new challenges for producers in the field of environmental protection, and related to the inclusion of cybernetic technology in physical production processes as well as distribution. Production starts and ends on the customer. Industry 4.0 is a collective term for technologies and concepts of value chain organization. The United Nations Organization for Industrial Development indicates the following environmental aspects in the perspective of the development of Industry 4.0, such as: climate change and limited access to resources, primarily to clean energy. It is assumed that changes in the production and functioning of economies will result in a decrease in the emission of harmful compounds into the atmosphere and increase the flexibility of activities for environmental protection. The purpose of this work is to present general directions of changes in the field of environmental protection in Industry 4.0. Authors present the following areas of change: energy management and material management. These areas are opportunities for environmental. In the category of threats, the growing costs of environmental protection and household expenses are pointed out. The work is based on a literature study and statistical data. Statistical data are used: integrated technologies, expenditure and costs of environmental protection, recycling of secondary raw materials and energy consumption for the EU and Poland.
\end{abstract}

Keywords: Industry 4.0, environment, protection, resources, economy 